\title{
Spatio-temporal Analysis of South Western States of Nigeria using Remote Sensing Techniques
}

\author{
Oseni A. E. ${ }^{1, *}$ and Ode G. O. ${ }^{2}$ \\ ${ }^{1,2}$ Department of Surveying and Geoinformatics, Bells University of Technology, Ota, Ogun State, Nigeria \\ Corresponding Author: *ayo_oseni@yahoo.com
}

https://doi.org/10.36263/nijest.2020.02.0196

\begin{abstract}
The south western states of Nigeria have witnessed urban growth over time and the effect of this is urban growth has resulted in loss of vegetation, waterbody, bare soil, mangroves and gain in built up area for residential and commercial purposes. This research utilizes Remote Sensing techniques in mapping of Land Use/Land Cover changes that has taken place in south western states of Nigeria between a period of 15 years from 2003 to 2018 at a five year interval using Multi temporal Landsat satellite images (MSS, TM, and ETM+).Using supervised classification algorithm, the images were classified into bare soil, built-up area, vegetation and water body, which was used to carry out change detection analysis or time series analysis. Change detection analyses were carried out on the imageries to obtain the physical expansion of the area due to various land use. Results obtained from the analysis of built-up area dynamics for fifteen years revealed that the states have been undergoing urban expansion processes at the detriment of other land cover. The expansion of the built-up area from the analysis shows that the urban center is spreading to adjoining non-built-up areas in all directions. The analysis and quantification of the spatial trend revealed that urban expansion patterns and developmental processes of the past trends and present trends can provide better understanding of the dynamics of spatial increase in built up area and guide for sustainable urban development planning for future urban growth.
\end{abstract}

Keywords: Land use, Urban expansion, Satellite imagery, Change detection, Supervised classification

\subsection{Introduction}

In an urban environment or our environment in general (either urban or rural), natural and humaninduced activity have resulted in changes in our environment. The natural state of our environment has been altered over years i.e. human activities such as construction of built up areas for either residential or commercial purposes have resulted in changes in the natural state of the environment. Activities such as flooding, global warming etc. among many can also be mentioned as part of the things causing changes in our environment. This research focuses on the land use/cover changes. Land cover data documents how much of a region is covered by forests, wetlands, impervious surfaces, agriculture, and other land and water types. Water types include wetlands or open water. Land use shows how people use the landscape - whether for development, conservation, or mixed uses. Land use land cover change also known as land change is therefore a general term for the human modification of earth's terrestrial surface (Perrings et al., 2011). Land is becoming a scarce resource due to immense agricultural and demographic pressure. Hence, information on land use / land cover and possibilities for their optimal use is essential for the selection, planning and implementation of land use schemes to meet the increasing demands for basic human needs and welfare. This information also assists in monitoring the dynamics of land use resulting out of changing demands of increasing population. Land use and land cover change has become a central component in current strategies for managing natural resources and monitoring environmental changes. The advancement in the concept of vegetation mapping has greatly increased research on land use land cover change thus providing an accurate evaluation of the spread and health of the world's forest and grassland, and agricultural resources has become an important priority. Viewing the earth from space is now crucial to the understanding of the influence of man's activities on his natural resource base over time. In 
situations of rapid and often unrecorded land use change, observations of the earth from space provide objective information of human utilization of the landscape. Land use land cover changes observation is going to be practically impossible or difficult and time consuming if not with the use of satellite imagery for analysis. The practice of observing land use land cover changes has improved with the help of remote sensing and geographic information system.

Remote Sensing (RS) and Geographic Information System (GIS) are now providing new tools for advanced ecosystem management. The collection of remotely sensed data facilitates the synoptic analyses of earth - system function, patterning, and change at local, regional and global scales over time; such data also provide an important link between intensive, localized ecological research and regional, national and international conservation and management of biological diversity (Wilkie and Finn, 1996).

Land cover classification has recently been a hot research topic for a variety of applications (Liang et al., 2002). According to Baulies and Szejwach (1998), during the next decades, land-use dynamics will play a major role in driving the changes of the global environment. Hence, global mapping of irrigated and dry land agriculture, semi-natural areas and forest cover, reflecting their dynamics, can contribute to the assessment of the biophysical implications of land use and land cover change within the earth's system.

Owoeye (2018) carried out a research that investigated the trend of urban sprawl and land cover change in Akure region between 1985 and 2014 using RS and GIS techniques with the view of examining the direction of the continuous expansion of the city. Findings revealed that the city grows sporadically which had unprecedented effects on the pattern of land uses within the city and in the adjoining settlements. There were incompatible conversions in land uses and undue encroachment into green areas in the adjoining communities. In his research, he suggests effective zoning strategy to check the indiscriminate nature of urban expansion whose effects on land use are well prominent in the study area.

Agene (2017) conducted a research around Obajana Kogi State Nigeria to monitor the effects of industrialization in the area. Two sets of Landsat images of 1987; 2001and Nigeria Sat-x image of 2012 underwent image processing and enhancement after which Maxim Likelihood Classification (MLC) was used to determine the changes over the past 25 years. The LULC analysis indicates a very high rate of land degradation and unplanned settlements over the past 25years (1987 to 2012) with an increase in settlements, bare surface, water bodies and a decrease in vegetation. Analysis showed that anthropogenic activities such as unplanned settlements and industrialization over the period of two decades ( 25 years) have affected the Land use land cover of the area greatly. Built-up in the study area witnessed anomalous increase up to $547.6 \%$ from 1987 to 2012 while vegetation decreased by $37.9 \%$ from 1987 to 2012.

In the study by Jande et al., (2019), the objectives were to map and determine the nature, extent and rate of land use and land cover changes, to analyze the Spatio-temporal land use and land cover change patterns and assess urban expansion in Gboko Local Government Area of Benue State, Nigeria. The emphasis was on determining the extent and rate of urban expansion in the area. The study focused on a period of 30 years; from 1987 to 2017. The result of the classification revealed that between 1987 and 2017, urban area increased from 3232ha (1.68\%) in 1987 to 8542ha (4.45\%) in 2007 and rose up to 16614 ha $(8.65 \%)$ in 2017 . Forest land on the other hand declined from 52108ha (27.13\%) to 46523 ha $(24.23 \%)$ down to 16723 ha $(8.71 \%)$ in the same period. Grassland was the dominant land cover occupying 69074ha (35.97\%) in 1987 increasing to 79874 ha $(41.59 \%)$ and 129715ha (67.54\%) in 2007 and 2017 respectively. The overall trend (1987-2017) revealed that urban area has increased up to $13382 \mathrm{ha}(9.01 \%)$ at an annual rate as high as $2.7 \%$ higher than the rate in the first period. Forest declined throughout the period with a loss of 5585ha $(12.57 \%)$ in the first period at the annual rate of $-2.51 \%$ and $29800 \mathrm{ha}(25.7 \%)$ in the second period at the annual rate of $-2.57 \%$. The overall trend shows that forest lost $35385 \mathrm{ha}(23.82 \%)$ at the rate of $-7.15 \%$. Farmland also decreased during the period losing 16006ha (36.03\%) in the first period at an annual rate of $-7.21 \%$ and $22317 \mathrm{ha}$ $(19.25 \%)$ in the second with an annual rate of change of -1.93 . From the result, it was evident that the rate of urban growth will continue and would certainly threaten forest areas in Gboko LGA. 
This research focuses on the changes in land use and land cover in the South western state of Nigeria, for a period of fifteen years at five years interval between 2003 to 2018 with the aim of discovering the changes that has occurred over time.

\subsection{Methodology}

The states of Nigeria are grouped into regions or geopolitical zones based on geographical, cultural, ethnic, and historical similarities. There are six regions or geopolitical zones in Nigeria. The six regions in Nigeria are: North Central, North West, North East, South South, South West, and South East. Figure 1 below shows the six geopolitical zones of Nigeria with different colour codes to indicate the states in the zones.

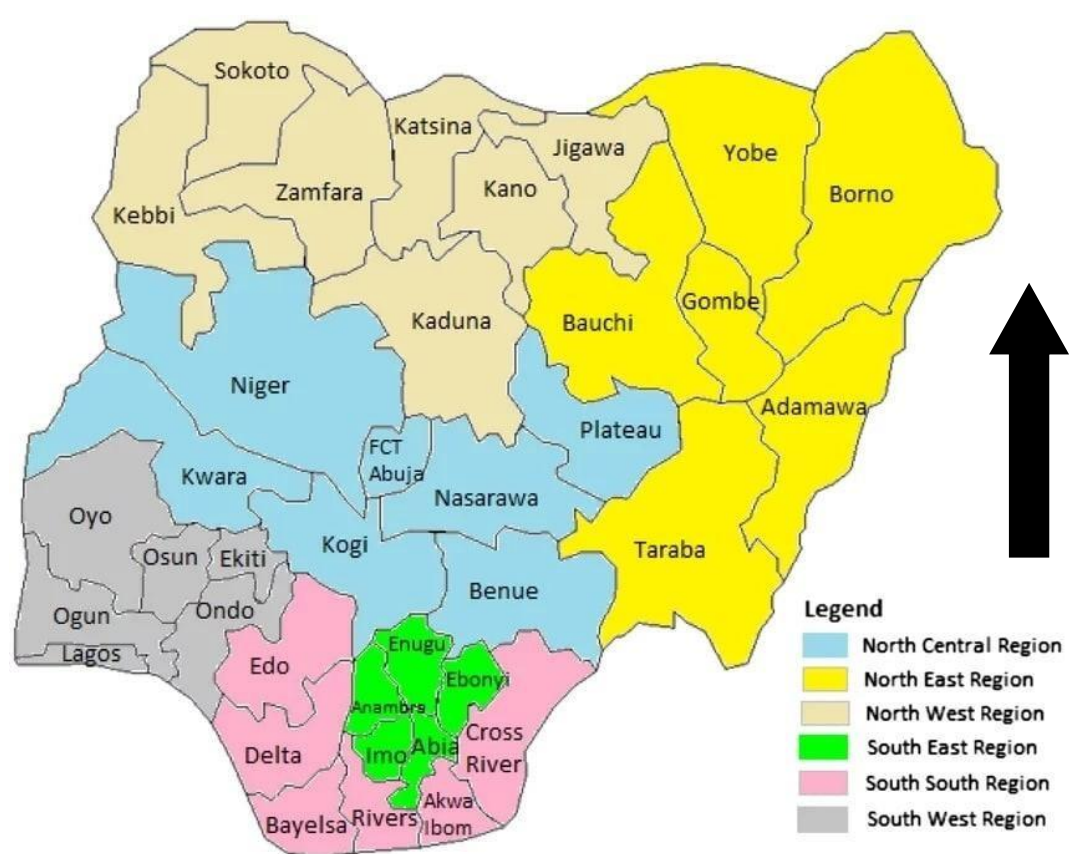

Figure 1: Map of Nigeria highlighting the geopolitical zones in the country

(Source: Ekong et al., 2012)

The states in the southwest region of Nigeria comprises of six states: Ekiti State, Lagos State, Ogun State, Ondo State, Osun State, Oyo State. Figure 2 below shows a map of the six states in the Southwestern region of Nigeria.

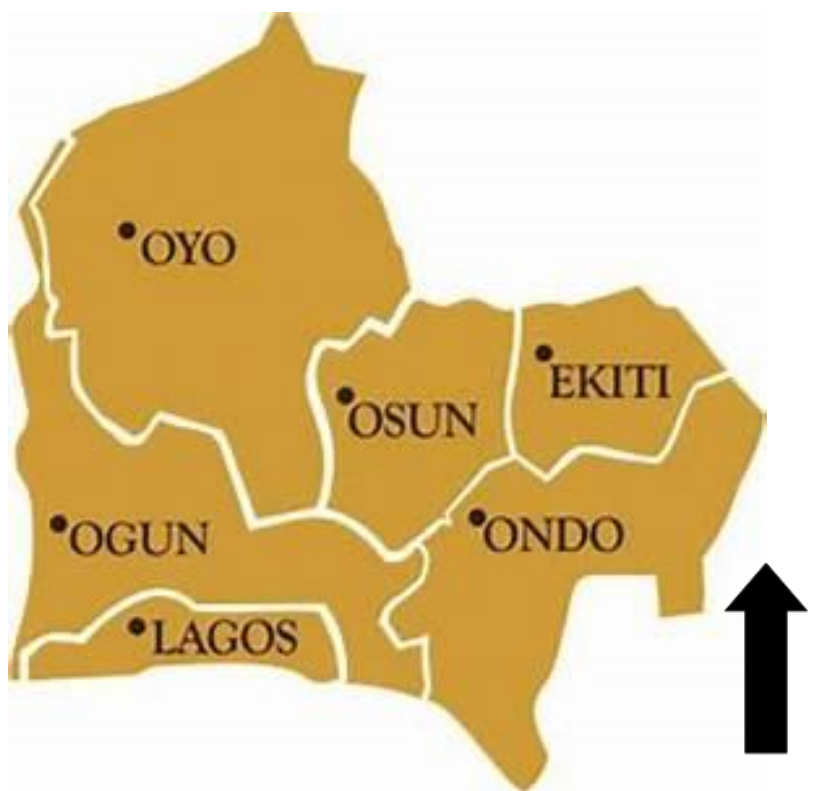

Figure 2: Map showing the location of states within the South West geopolitical zone in Nigeria (Source: Ekong et al., 2012) 


\subsection{Data acquisition}

This study utilized satellite imageries from Landsat 7 Enhanced Thematic Mapper Plus (ETM+) of 2003, 2008, 2013, and 2018 acquired from the United States Geological Surveys (USGS) Earth Explorer online portal. Figure 3 shows the image processing algorithms which involves layer stacking, clipping of the study area, image preprocessing, supervised classification and the thematic land cover.

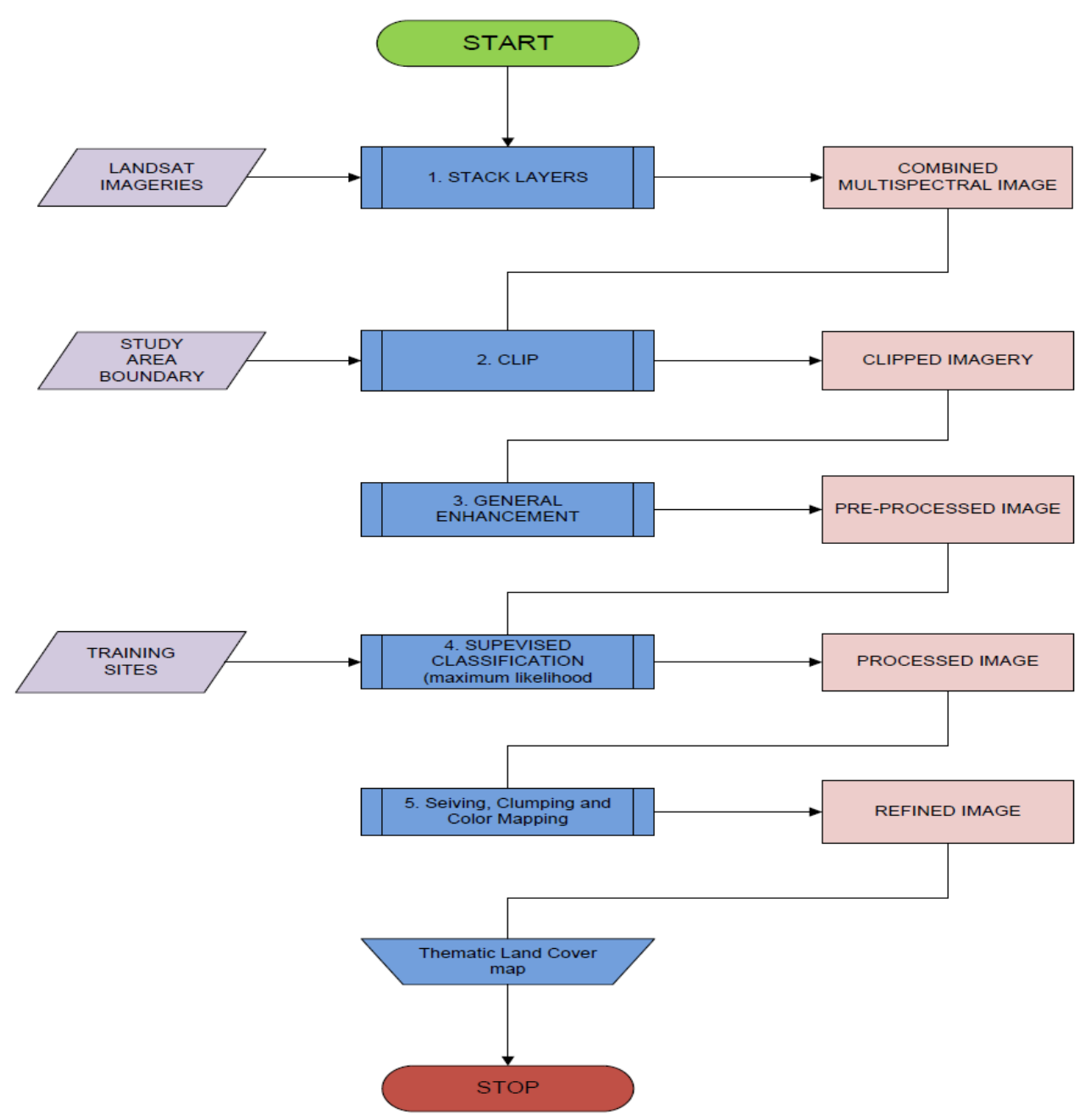

Figure 3: Workflow diagram for image processing algorithms

\subsection{Scan line correction}

Landsat 7 ETM+ operated with scan line corrector disabled since May 2003. Most of the imageries acquired had the scan line error; thereby the error was corrected using ENVI software with the extension called gap-fill.

\subsection{Image classification technique}

The preliminary interpretation of the Landsat imageries involved categorizing the study area land covers with four spectral classes, namely: Bare Soil, Vegetated Soil, Water Bodies and Built-up areas. The classification was categorized into CORINE Land Cover nomenclature.

Next, a step by step process of training class selection based on the spectral signatures of each class and ancillary data was done with ArcMap 10.3 software. Care was taken to avoid inclusion of mixed pixels in the training classes so as not to compromise the fidelity of the output classes. Then supervised classification of the imageries was performed using the Maximum Likelihood Classification technique. Maximum likelihood classification involves classification of the image using available spectral data to label pixel which has been made up of a particular spectral class (Ndukwe, 1997). Maximum likelihood classification assumes that the statistics for each class in each band are 
normally distributed and calculates the probability that a given pixel belongs to a specific class, unless you select a probability threshold, all pixels are classified. Each pixel is assigned to the class that has the highest probability (that is, the maximum likelihood). If the highest probability has a value lower than a threshold you specify, the pixel remains unclassified.

The image processing software (ArcMap 10.3, ENVI 5.0) implements maximum likelihood classification by calculating the following discriminant functions for each pixel in the image (Richards 1999):

$$
g_{i}(x)=\ln p\left(\omega_{i}\right)-\frac{1}{2} \ln \left|\sum i\right|-\frac{1}{2}\left(x-m_{i}\right)^{T} \sum_{i}^{-1}\left(x-m_{i}\right)
$$

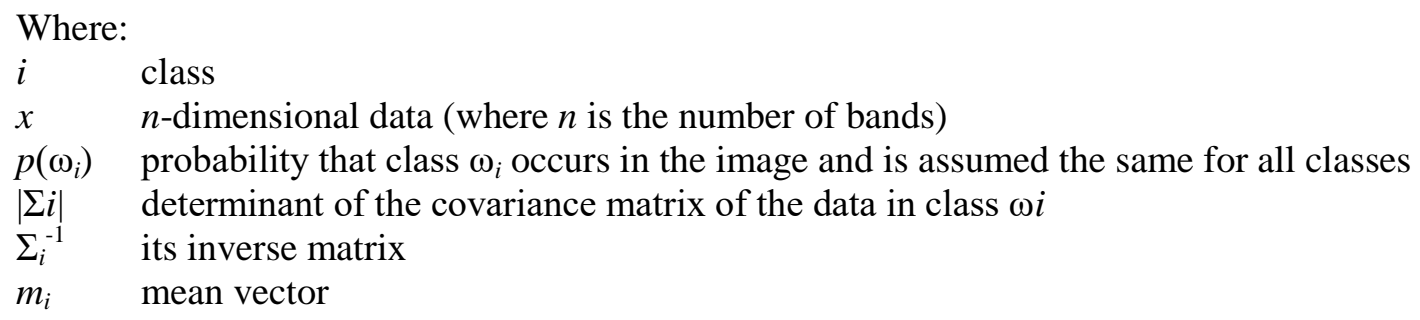

The classification procedure revolved round these four (4) sequential steps: create and analyse the input data (imagery etc.), produce training classes (ROIs), evaluate and, if necessary, edit training classes and perform the classification.

\subsubsection{Classification scheme}

Studies of land use and land cover structure change usually needs development and definition of more or less homogeneous land use/land cover units before the analysis is started. These have to be defined and spatially differentiated using the available data sources (e.g. remote sensing) and any other relevant information and local knowledge. Hence, the land cover classes used in this research are defined based on the CORINE land cover. CORINE land cover is a map of the European environmental landscape based on the interpretation of satellite images. It provides comparable digital maps of land cover for each country for much of Europe. This has been useful for environmental analysis and for policy makers. The acronym CORINE stands for Coordination of Information on Environment. The European Union established CORINE in 1985 to create pan- European database on land cover, biotopes (habitat), soil maps and acid rain. The land cover project in CORINE programmed works with land cover nomenclature with three levels: first level having five headings; second level having fifteen headings and third level having forty-four headings. It has a working scale of 1/100000 with a minimum mapping unit of 25 hectare (EEA, 2018). In so doing, initially, 8 land cover classes were selected and these were further grouped into four classes as shown in Table 1. The land use/land cover change detection analyses are based on these classes.

Table 1: Land cover classes and descriptions

\begin{tabular}{ll}
\hline Land cover classes & Descriptions \\
\hline Built up (artificial) surfaces & $\begin{array}{l}\text { This classes includes infrastructural structure, industrial, } \\
\text { commercial, transport units and other related built up areas of } \\
\text { non-agricultural vegetated areas. } \\
\text { Crop, pasture, irrigated land and plantation are included in this } \\
\text { class, heterogeneous agricultural areas, vegetated areas and } \\
\text { agricultural areas (forest, shrubs and semi-natural areas) } \\
\text { mixed forest land, herbaceous vegetation association. }\end{array}$ \\
& $\begin{array}{l}\text { Open spaces with little or no vegetation, beaches, dunes sands, } \\
\text { bare rocks, sparsely vegetated areas. } \\
\text { Water courses, water bodies, sea and ocean areas, coastal lagoons. }\end{array}$ \\
Water- bodies &
\end{tabular}

\subsection{Accuracy assessment}

At the post interpretation stage of this exercise, accuracy assessment was carried out. Accuracy assessment is the major computation and evaluation of classified results. Accuracy assessment is the 
agreement between remote sensing data (classified image) and reference information data. It compares classified image to an image which is assumed to be correct (such as an aerial photo). This task is accomplished by compiling an error matrix. An error matrix is a table of values that compares the value assigned during classification process to the actual value from an aerial photo. These are compared on a point-by-point basis. A random set of points is generated for the region covered by the area. Then using the aerial photos, the value for each point is identified. Then, these same random points are used to identify each point's known value in the classified image. The error matrix is completed by comparing these two values.

Creation of Random Points: A set of random points (100) was generated using the -Create Random Points tool under Data Management tools.

Identifying Random Point Values from Aerial Imagery (Google Earth): The classified images for the study area were checked and verified using Google Earth and this was done by extracting coordinates on Google earth and overlaying it on the classified images on the different classes (Water bodies, Vegetated Soil, Bare Soil, and Built-up areas).

\subsection{Area and percentage calculation}

\subsubsection{Area calculation of State boundary}

The area calculation $\left(\mathrm{km}^{2}\right)$ of each state was obtained from the boundary shape-file of the state, using the calculate geometry option in the attribute table. This operation was carried out using ArcMap. Table 2 below shows the area covered by each state in the southwestern region of Nigeria. The states cover a total area of $77748.16 \mathrm{~km}^{2}$.

Table 2: Total area calculation of each State in the zone

\begin{tabular}{ll}
\hline States & Area $\left(\mathrm{km}^{2}\right)$ \\
\hline Ekiti & 5801.49 \\
Lagos & 3619.52 \\
Ogun & 16882.98 \\
Ondo & 15000.23 \\
Osun & 8595.12 \\
Oyo & 27848.82 \\
\hline Total & 77748.16 \\
\hline
\end{tabular}

\subsubsection{Area calculation for each class}

The formula above was used to obtain the area of each class (water bodies, bare soil, vegetated soil and built-up areas). The 900 divided by 1 million was used to convert each pixel area to kilometer squared then multiplied by the number of pixel count per class to give the area of the class of interest. This was actually done using ArcMap.

Area of class $=$ pixel count per class $\times(900 / 1000000)$

\subsubsection{Percentage cover for each class}

The formula above gave the percentage cover for each class; this was also done using Microsoft Excel. The total area for each state was obtained on Microsoft Excel, after exporting the attribute table to Microsoft Excel. The percentage cover for each class of each state in the study area was used to obtain the graph of the changes from epoch to epoch for each state.

Percentage cover per class $=($ Area per class $/$ Total Area $) \times 100$

\subsection{Multi temporal analysis (change/trend detection)}

To analyze the trend of changes in the classified features from one epoch to another, tables/charts showing the area in kilometer square and the percentage change for each year $(2003,2008,2013$, and 2018) measured against each land cover was developed. 
Percentage change to determine the trend of change was then calculated by dividing observed change by sum of changes multiplied by 100 .

(Trend) percentage change $=X / Y \times 100$

\author{
Where: \\ $X \quad$ observed change \\ $Y \quad$ sum of change.
}

In obtaining annual rate of change, the percentage change is divided by 100 and multiplied by the number of study years 2003 - 2008 (5years), 2008 - 2013 (5years), $2013-2018$ (5 years).

\title{
3.0. Results and Discussion
}

The following are the results obtained from individual states and collated states as a zone for different epochs.

\subsection{Ekiti State}

The land cover distribution of Ekiti State for the 4 years is shown in Table 3. The table reveals that bare soil lost to the other land cover classes from $35.54 \%$ to $3.31 \%$ within 2003 to 2013 and appreciated within 2013 to 2018 from $3.31 \%$ to $19.42 \%$. Vegetated soil occupied an average of $61.18 \%$ of the area in 4 years put together within the same period; water-bodies also had an average of $0.44 \%$ of the area. Built-up areas appreciated within 2003 to 2013 from $11.28 \%$ to $31.60 \%$ and had a slight decrease from $31.60 \%$ to $29.52 \%$ within 2013 to 2018 .

Table 3: Land cover distribution of Ekiti State (2003, 2008, 2013, and 2018)

\begin{tabular}{|l|l|l|l|l|l|l|l|l|}
\hline \multirow{2}{*}{ Feature class } & \multicolumn{2}{|c|}{2003} & \multicolumn{2}{c|}{2008} & \multicolumn{2}{c|}{2013} & \multicolumn{2}{c|}{2018} \\
\cline { 2 - 9 } & Area $\left(\mathrm{km}^{2}\right)$ & Area $(\%)$ & Area $\left(\mathrm{km}^{2}\right)$ & Area $(\%)$ & Area $\left(\mathrm{km}^{2}\right)$ & Area $(\%)$ & Area $\left(\mathrm{km}^{2}\right)$ & Area $(\%)$ \\
\hline Bare soil & 2061.75 & 35.54 & 509.80 & 8.79 & 191.86 & 3.31 & 1126.70 & 19.42 \\
\hline Vegetated soil & 3079.21 & 53.08 & 4392.55 & 75.71 & 3770.42 & 64.99 & 2955.13 & 50.94 \\
\hline Water bodies & 6.39 & 0.11 & 6.19 & 0.11 & 5.87 & 0.10 & 7.07 & 0.12 \\
\hline Built up areas & 654.15 & 11.28 & 892.96 & 15.39 & 1833.34 & 31.60 & 1712.58 & 29.52 \\
\hline Total & 5801.49 & 100.00 & 5801.49 & 100.00 & 5801.49 & 100.00 & 5801.49 & 100.00 \\
\hline
\end{tabular}

Table 4: Trend of land cover changes in Ekiti State for 2003, 2008, 2013 and 2018

\begin{tabular}{|c|c|c|c|c|c|c|c|c|c|}
\hline \multirow[b]{2}{*}{ Feature Class } & \multicolumn{2}{|c|}{$2003-2008$} & \multicolumn{2}{|c|}{$2008-2013$} & \multicolumn{2}{|c|}{$2013-2018$} & \multicolumn{3}{|c|}{ Annual rate of change } \\
\hline & $\begin{array}{l}\text { Area } \\
\text { change } \\
\left(\mathrm{km}^{2}\right)\end{array}$ & $\begin{array}{l}\% \\
\text { change }\end{array}$ & $\begin{array}{l}\text { Area } \\
\text { change } \\
\left(\mathrm{km}^{2}\right)\end{array}$ & $\begin{array}{l}\% \\
\text { change }\end{array}$ & $\begin{array}{l}\text { Area } \\
\text { change } \\
\left(\mathrm{km}^{2}\right)\end{array}$ & $\begin{array}{l}\% \\
\text { change }\end{array}$ & $\begin{array}{l}2003- \\
2008(\%)\end{array}$ & $\begin{array}{l}2008- \\
2013(\%)\end{array}$ & $\begin{array}{l}2013- \\
2018(\%)\end{array}$ \\
\hline Bare soil & -1551.95 & -50.00 & -317.93 & -16.90 & 934.84 & 49.94 & -2.50 & -0.85 & 2.50 \\
\hline Vegetated soil & 1313.34 & 42.32 & -622.12 & -33.08 & -815.29 & -43.55 & 2.12 & -1.65 & -2.18 \\
\hline Water bodies & -0.20 & -0.01 & -0.32 & -0.02 & 1.21 & 0.06 & 0.00 & 0.00 & 0.00 \\
\hline Built up areas & 238.81 & 7.69 & 940.38 & 50.00 & -120.76 & -6.45 & 0.38 & 2.50 & -0.32 \\
\hline Total change & 3103.59 & 100.00 & 1880.75 & 100.00 & 1872.1 & 100.00 & & & \\
\hline
\end{tabular}

Change detection analysis (Table 4) reveals that there was remarkable decrease in annual rate of change in the bare soil within Ekiti state, the results shows that between 2003 to 2008, it was (-2.50\%) and $(-0.85 \%)$ between 2008 and 2013, while during the period of 2013 to 2018 there was an increase with an annual rate of change of $+2.50 \%$. Vegetation gained with an annual rate of change of $2.12 \%$ (2003-2008), and lost with an annual rate of change of 1.65\% (2008-2013) and -2.18\% (2013-2018). Built up areas between 2003 and 2008 was representing $7.68 \%$ changes with an annual rate of $0.38 \%$. From 2008-2013, the annual rate of change was 2.50\%, and between 2013 and 2018, it lost with an annual rate of change of $(-0.32 \%)$.

Figure 4 to Figure 7 shows the various land use by the different classes between 2003 and 2018. The area of increase and decrease of each class is shown the map. 

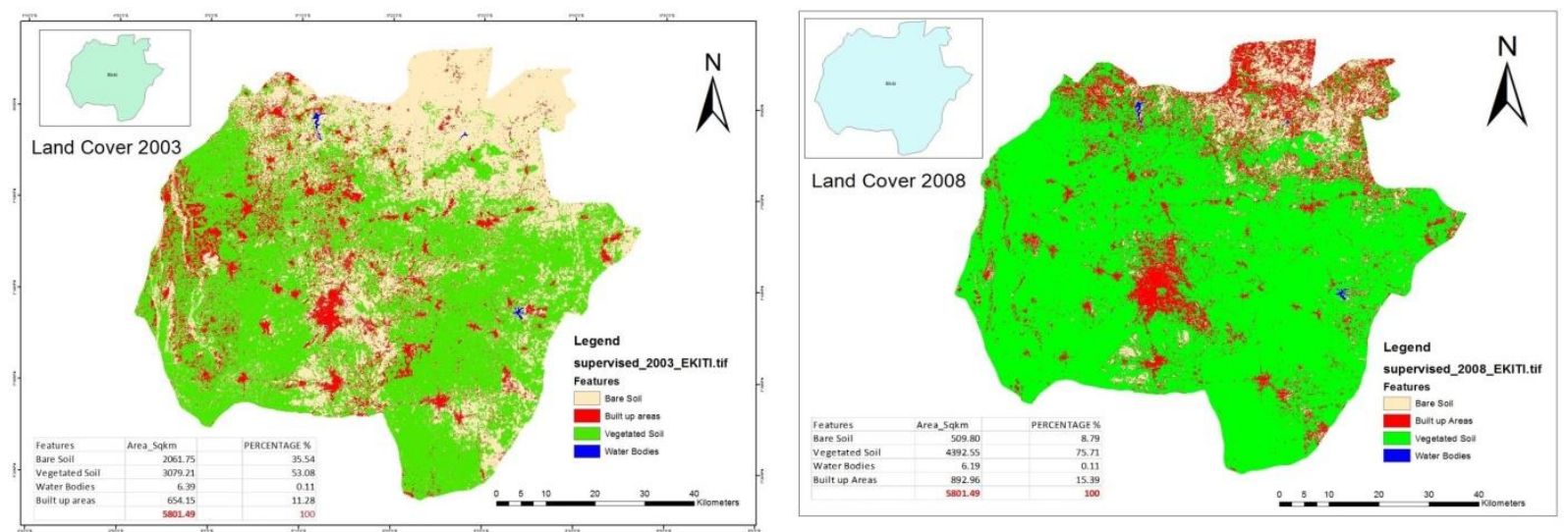

Figure 4: Land cover map - Ekiti 2003

Figure 5: Land cover map - Ekiti 2008
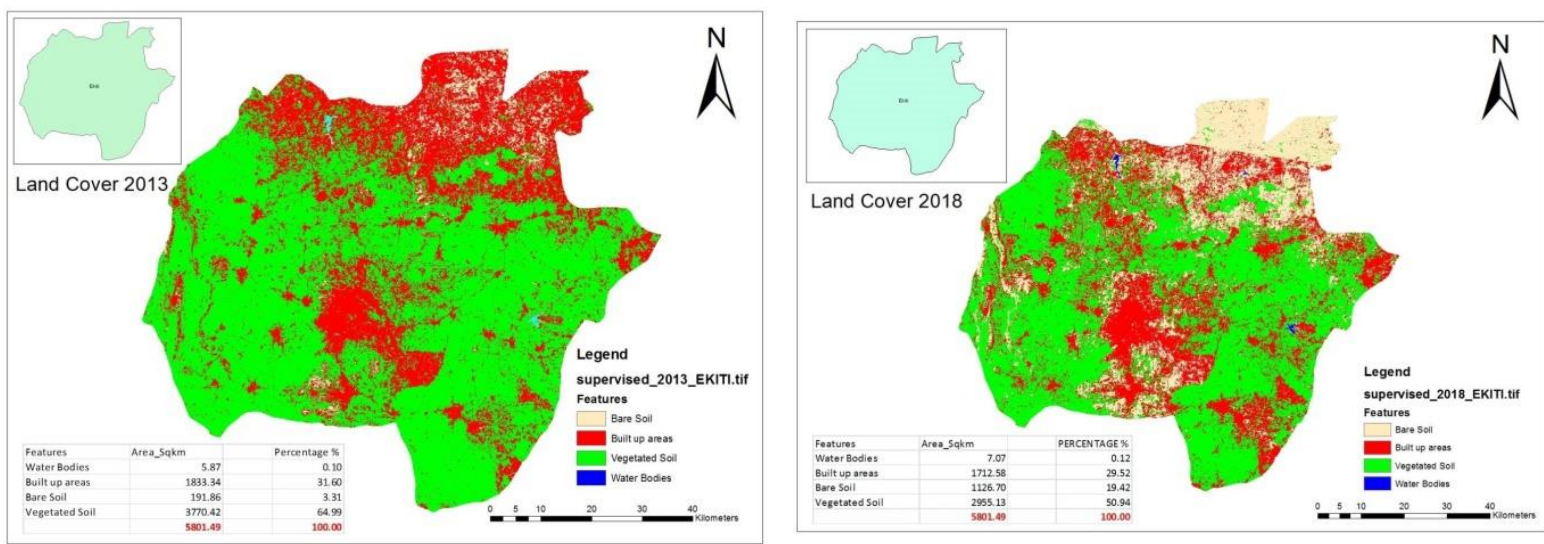

Figure 6: Land cover map - Ekiti 2013

Figure 7: Land cover map - Ekiti 2018

\subsection{Lagos State}

The land cover distribution of Lagos State for the 4 periods is shown in Table 5. The table reveals that bare soil depreciated within the study period from $8.22 \%$ to $0 \%$. Vegetated soil occupied an average of $51.96 \%$ of the area in 4 periods put together. Water bodies also had an average of $18.29 \%$ of the study area. There was a general increase in the coverage area of built up areas within the study period from $13.72 \%$ to $30.79 \%$.

Table 5: Land cover distribution of Lagos State (2003, 2008, 2013, and 2018)

\begin{tabular}{|l|l|l|l|l|l|l|l|l|}
\hline \multirow{2}{*}{ Feature class } & \multicolumn{2}{|c|}{2003} & \multicolumn{2}{c|}{2008} & \multicolumn{2}{c|}{2013} & \multicolumn{2}{c|}{2018} \\
\cline { 2 - 9 } & Area $\left(\mathrm{km}^{2}\right)$ & Area $(\%)$ & Area $\left(\mathrm{km}^{2}\right)$ & Area $(\%)$ & Area $\left(\mathrm{km}^{2}\right)$ & Area $(\%)$ & Area $\left(\mathrm{km}^{2}\right)$ & Area $(\%)$ \\
\hline Bare soil & 297.53 & 8.22 & 160.13 & 4.42 & 76.45 & 2.11 & 0.00 & 0.00 \\
\hline Vegetated soil & 2141.08 & 59.15 & 1897.83 & 52.43 & 1547.28 & 42.75 & 1935.95 & 53.49 \\
\hline Water bodies & 684.38 & 18.91 & 699.90 & 19.34 & 694.21 & 19.18 & 569.00 & 15.72 \\
\hline Built up areas & 496.53 & 13.72 & 861.66 & 23.81 & 615.04 & 16.99 & 1114.58 & 30.79 \\
\hline Cloud cover & 0.00 & 0.00 & 0.00 & 0.00 & 686.55 & 18.97 & 0.00 & 0.00 \\
\hline Total & 3619.52 & 100.00 & 3619.52 & 100.00 & 3619.52 & 100.00 & 3619.52 & 100.00 \\
\hline
\end{tabular}

Table 6: Trend of land cover changes in Lagos State for 2003, 2008, 2013 and 2018

\begin{tabular}{|c|c|c|c|c|c|c|c|c|c|}
\hline \multirow[b]{2}{*}{ Feature class } & \multicolumn{2}{|c|}{$2003-2008$} & \multicolumn{2}{|c|}{$2008-2013$} & \multicolumn{2}{|c|}{$2013-2018$} & \multicolumn{3}{|c|}{ Annual rate of change } \\
\hline & $\begin{array}{l}\text { Area } \\
\text { change } \\
\left(\mathrm{km}^{2}\right)\end{array}$ & $\begin{array}{l}\% \text { of } \\
\text { change }\end{array}$ & $\begin{array}{l}\text { Area } \\
\text { change } \\
\left(\mathrm{km}^{2}\right)\end{array}$ & $\begin{array}{l}\% \text { of } \\
\text { change }\end{array}$ & $\begin{array}{l}\text { Area } \\
\text { change } \\
\left(\mathrm{km}^{2}\right)\end{array}$ & $\begin{array}{l}\% \text { of } \\
\text { change }\end{array}$ & $\begin{array}{l}2003- \\
2008 \\
(\%)\end{array}$ & $\begin{array}{l}2008- \\
2013 \\
(\%)\end{array}$ & $\begin{array}{l}2013- \\
2018 \\
(\%)\end{array}$ \\
\hline Bare soil & -137.40 & -18.05 & -83.68 & -12.19 & -76.45 & -7.01 & -0.90 & -0.61 & -0.35 \\
\hline Vegetated soil & -243.25 & -31.95 & -350.55 & -51.06 & 388.67 & 35.66 & -1.60 & -2.55 & 1.78 \\
\hline Water bodies & 15.51 & 2.04 & -5.68 & -0.83 & -125.22 & -11.49 & 0.10 & -0.04 & -0.57 \\
\hline Built up areas & 365.14 & 47.96 & -246.63 & -35.92 & 499.54 & 45.83 & 2.40 & -1.80 & 2.29 \\
\hline Total change & 761.3 & 100.00 & 686.54 & 100.00 & 1089.88 & 100.00 & & & \\
\hline
\end{tabular}

Change detection analysis (Table 6) reveals that there was remarkable decrease in annual rate of change in the bare soil within Lagos state, the results show that between 2003 to 2008 it was ($0.90 \%),(-0.61 \%)$ in 2008 to 2013, and (-0.35) in 2013 to 2018. Vegetated soil lost with an annual rate 
of $-1.60 \%$ (2003-2008) and -2.55 (2008-2013), and gained between with an annual rate of $1.78 \%$ (2013-2018). Water bodies represented $2.04 \%$ changes with an annual rate of $0.10 \%$ between 2003 and 2008. From 2008 to 2013, the annual rate of change was $-0.04 \%$ and $-0.57 \%$ (2013-2018). During the period of 2003 and 2008, built-up area was representing $47.96 \%$ changes with an annual rate of $2.40 \%$. From 2008 to 2013, the annual rate of change was $-1.80 \%$, and $2.29 \%$ between 2013 and 2018.

Figure 8 to Figure 11 shows the various land use by the different classes between 2003 and 2018. The area of increase and decrease of each class is shown the map.

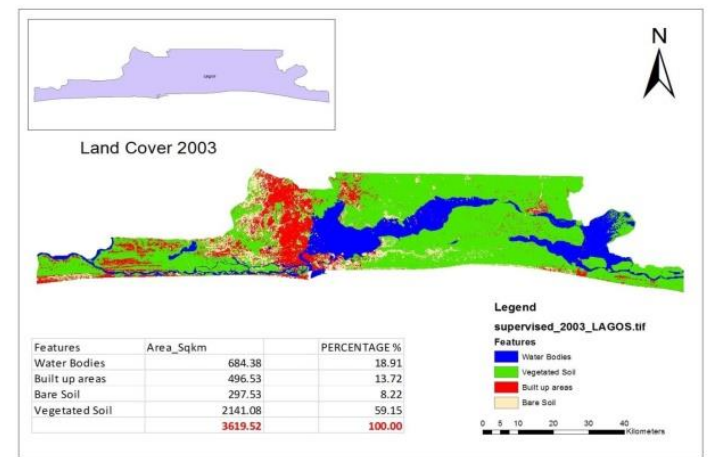

Figure 8: Land cover map - Lagos 2003

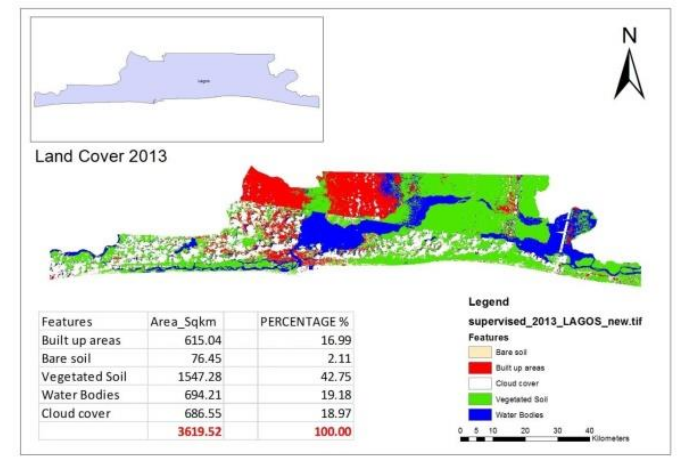

Figure 10: Land cover map - Lagos 2013

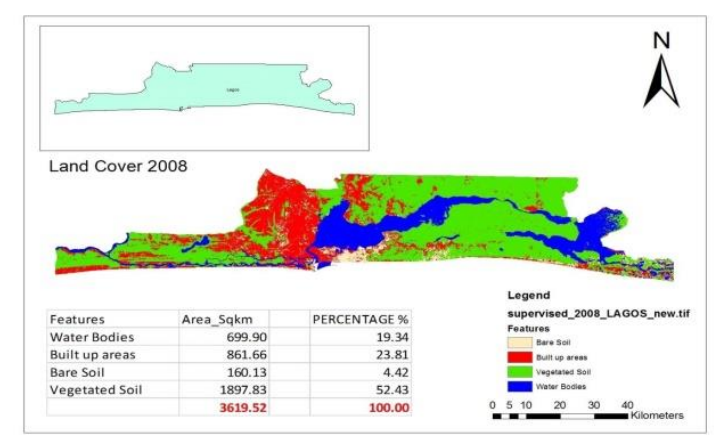

Figure 9: Land cover map - Lagos 2008

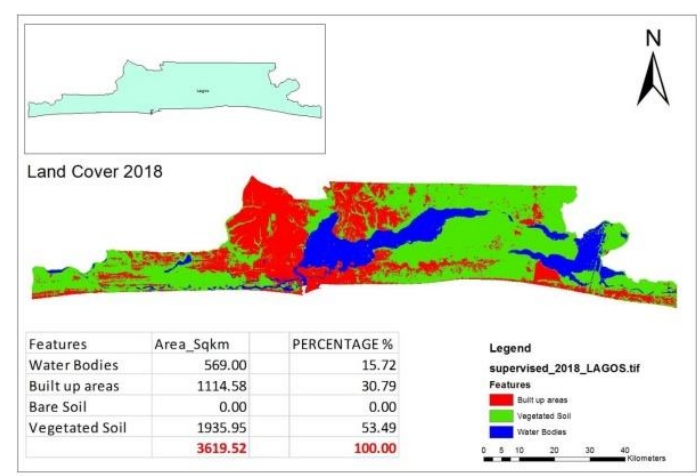

Figure 11: Land cover map - Lagos 2018

\subsection{Ogun State}

The land cover distribution of Ogun State for the 4 periods is shown in Table 7. The table reveals that bare soil depreciated within the study period from $6.92 \%$ to $1.09 \%$. Vegetated soil appreciated in 2008 and later depreciated by $64.17 \%$ in 4 periods. Water bodies appreciated and later depreciated in 2018 in the study area. There built up area appreciated between 2008 to $201318.33 \%$ to $44.45 \%$ and depreciated to $34.03 \%$ in 2018.

Table 7: Land cover distribution of Ogun State (2003, 2008, 2013, and 2018)

\begin{tabular}{|l|l|l|l|l|l|l|l|l|}
\hline \multirow{2}{*}{ Feature Class } & \multicolumn{2}{|c|}{2003} & \multicolumn{2}{c|}{2008} & \multicolumn{2}{c|}{2013} & \multicolumn{2}{c|}{2018} \\
\cline { 2 - 10 } & Area $\left(\mathrm{km}^{2}\right)$ & Area $(\%)$ & Area $\left(\mathrm{km}^{2}\right)$ & Area $(\%)$ & Area $\left(\mathrm{km}^{2}\right)$ & Area $(\%)$ & Area $\left(\mathrm{km}^{2}\right)$ & Area $(\%)$ \\
\hline Bare soil & 1168.49 & 6.92 & 260.64 & 1.54 & 183.65 & 1.09 & 184.49 & 1.09 \\
\hline Vegetated soil & 11219.05 & 66.45 & 12900.50 & 76.41 & 8649.81 & 51.23 & 10833.84 & 64.17 \\
\hline Water bodies & 32.11 & 0.19 & 170.23 & 1.01 & 59.14 & 0.35 & 119.21 & 0.71 \\
\hline Built up areas & 4366.74 & 25.86 & 3094.79 & 18.33 & 7503.87 & 44.45 & 5745.45 & 34.03 \\
\hline Cloud cover & 96.61 & 0.57 & 456.82 & 2.71 & 486.52 & 2.88 & 0.00 & 0.00 \\
\hline Total & 16882.98 & 100.00 & 16882.98 & 100.00 & 16882.98 & 100.00 & 16882.98 & 100.00 \\
\hline
\end{tabular}


Table 8: Trend of land cover changes in Ogun State for 2003, 2008, 2013 and 2018

\begin{tabular}{|c|c|c|c|c|c|c|c|c|c|}
\hline \multirow[b]{2}{*}{ Feature class } & \multicolumn{2}{|c|}{$2003-2008$} & \multicolumn{2}{|c|}{$2008-2013$} & \multicolumn{2}{|c|}{ 2013-2018 } & \multicolumn{3}{|c|}{ Annual rate of change } \\
\hline & $\begin{array}{l}\text { Area } \\
\text { change } \\
\left(\mathrm{km}^{2}\right)\end{array}$ & $\begin{array}{l}\% \text { of } \\
\text { change }\end{array}$ & $\begin{array}{l}\text { Area } \\
\text { change } \\
\left(\mathrm{km}^{2}\right)\end{array}$ & $\begin{array}{l}\% \text { of } \\
\text { change }\end{array}$ & $\begin{array}{l}\text { Area } \\
\text { change } \\
\left(\mathrm{km}^{2}\right)\end{array}$ & $\begin{array}{l}\% \text { of } \\
\text { change }\end{array}$ & $\begin{array}{l}2003- \\
2008 \\
(\%)\end{array}$ & $\begin{array}{l}2008- \\
2013 \\
(\%)\end{array}$ & $\begin{array}{l}2008- \\
2013 \\
(\%)\end{array}$ \\
\hline Bare soil & -907.85 & -22.70 & -76.99 & -0.87 & 0.84 & 0.02 & -1.13 & -0.04 & 0.00 \\
\hline Vegetated soil & 1681.45 & 42.04 & -4250.69 & -48.04 & 2184.03 & 54.55 & 2.10 & -2.40 & 2.73 \\
\hline Water bodies & 138.12 & 3.45 & -111.09 & -1.26 & 60.07 & 1.50 & 0.17 & -0.06 & 0.08 \\
\hline Builtup areas & -1271.94 & -31.80 & 4409.07 & 49.83 & -1758.42 & -43.92 & -1.59 & 2.49 & -2.20 \\
\hline Total change & 3999.36 & 100.00 & 8847.84 & 100.00 & 4003.36 & 100.00 & & & \\
\hline
\end{tabular}

Change detection analysis (Table 8) reveals that there was remarkable decrease in annual rate of change in the bare soil within Ogun State, the results show that between 2003 to 2008 sand 2008 to 2013. Vegetated soil gained with an annual rate of $2.10 \%$ (2003-2008) and decreased by -2.40 (20082013), and gained between with an annual rate of 2.73\% (2013-2018). Water bodies changed with an annual rate of $0.17 \%$ between 2003 and 2008. From 2008 to 2013, there was a decrease in annual rate of change was $-0.06 \%$ and increase $-0.08 \%$ (2013-2018). The built-up area annual rate change increased between $2008-2013$ of $2.49 \%$.

Figure 12 to Figure 15 shows the various land use by the different classes between 2003 and 2018 . The area of increase and decrease of each class is shown the map.

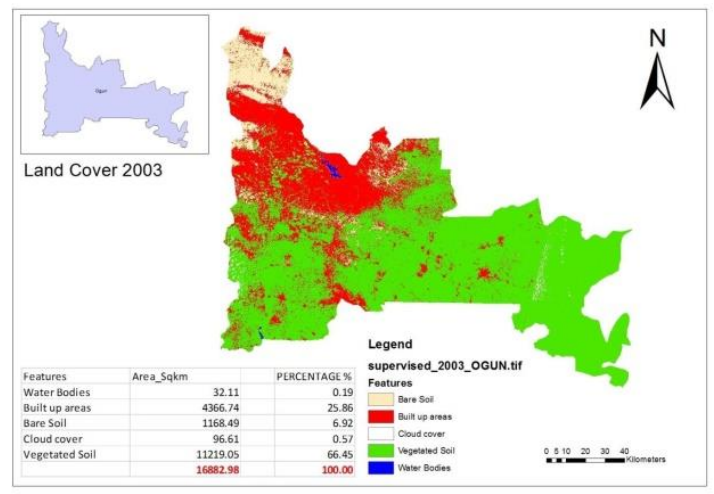

Figure 12: Land cover map - Ogun 2003

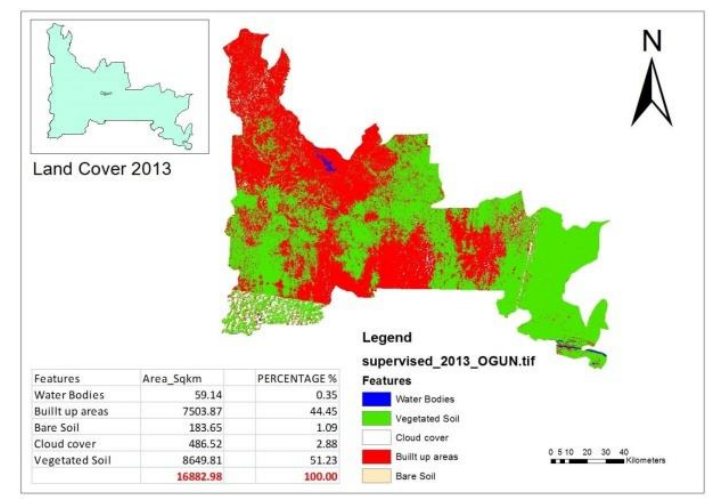

Figure 14: Land cover map - Ogun 2013

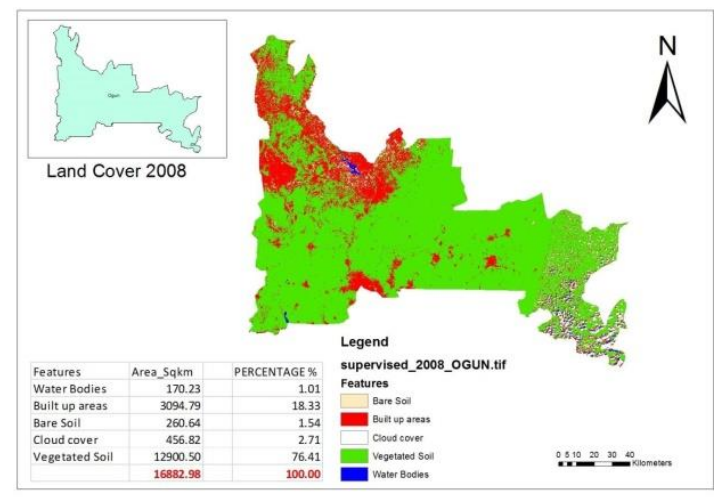

Figure 13: Land cover map - Ogun 2008

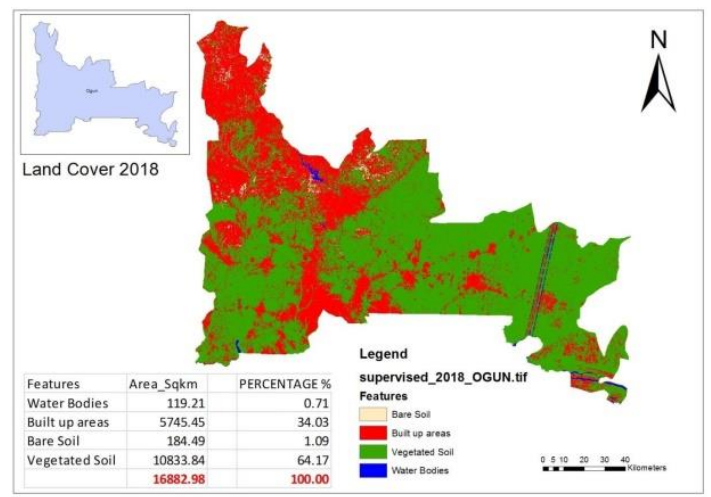

Figure 15: Land cover map - Ogun 2018

\subsection{Ondo State}

The land cover distribution of Ondo State for the 4 periods is shown in Table 9. The table reveals that bare soil depreciated within the study period from $13.36 \%$ to $2.74 \%$. Vegetated soil decreased in 2008 and increased in 2013 and decreased in 2018. Water bodies decreased in 2003, 2008, 2013 and increased in 2018. There was a general increase in the coverage area of built up areas within the study period from 2003, 2008, 2013 and decreased in 2018. 
Table 9: Land cover distribution of Ondo State (2003, 2008, 2013, and 2018)

\begin{tabular}{|l|l|l|l|l|l|l|l|l|}
\hline \multirow{2}{*}{ Feature class } & \multicolumn{2}{|c|}{2003} & \multicolumn{2}{c|}{2008} & \multicolumn{2}{c|}{2013} & \multicolumn{2}{c|}{2018} \\
\cline { 2 - 10 } & Area $\left(\mathrm{km}^{2}\right)$ & Area $(\%)$ & Area $\left(\mathrm{km}^{2}\right)$ & Area $(\%)$ & Area $\left(\mathrm{km}^{2}\right)$ & Area $(\%)$ & Area $\left(\mathrm{km}^{2}\right)$ & Area $(\%)$ \\
\hline Bare soil & 3435.08 & 22.90 & 2004.19 & 13.36 & 410.36 & 2.74 & 2582.68 & 17.22 \\
\hline Vegetated soil & 10484.30 & 69.89 & 7373.05 & 49.15 & 12469.74 & 83.13 & 11086.26 & 73.91 \\
\hline Water bodies & 51.89 & 0.35 & 45.89 & 0.31 & 32.66 & 0.22 & 83.75 & 0.56 \\
\hline Built up areas & 693.35 & 4.62 & 847.79 & 5.65 & 2087.47 & 13.92 & 1247.54 & 8.32 \\
\hline Cloud cover & 335.61 & 2.24 & 4729.31 & 31.53 & 0.00 & 0.00 & 0.00 & 0.00 \\
\hline Total & 15000.23 & 100.00 & 15000.23 & 100.00 & 15000.23 & 100.00 & 15000.23 & 100.00 \\
\hline
\end{tabular}

Table 10: Trend of land cover changes in Ondo State for 2003, 2008, 2013 and 2018

\begin{tabular}{|l|l|l|l|l|l|l|l|l|l|l|}
\hline \multirow{2}{*}{ Feature class } & \multicolumn{2}{|c|}{$2003-2008$} & \multicolumn{2}{|c|}{$2008-2013$} & \multicolumn{2}{c|}{$2013-2018$} & \multicolumn{3}{|c|}{ Annual rate of change } \\
\cline { 2 - 11 } & $\begin{array}{l}\text { Area } \\
\text { change }\end{array}$ & $\begin{array}{l}\% \\
\text { change }\end{array}$ & $\begin{array}{l}\text { Area } \\
\text { change }\end{array}$ & $\begin{array}{l}\% \text { of } \\
\text { change }\end{array}$ & Area change & $\begin{array}{l}\% \\
\text { change }\end{array}$ & $\begin{array}{l}2003- \\
2008 \\
(\%)\end{array}$ & $\begin{array}{l}2003- \\
2013 \\
(\%)\end{array}$ & $\begin{array}{l}2013- \\
2018 \\
(\%)\end{array}$ \\
\hline Bare soil & -1430.89 & -30.43 & -1593.83 & -20.06 & 2172.32 & 48.85 & -1.52 & -1.00 & 2.44 \\
\hline Vegetated soil & -3111.25 & -66.16 & 5096.69 & 64.16 & -1383.49 & -31.11 & -3.31 & 3.21 & -1.56 \\
\hline Water bodies & -6.01 & -0.13 & -13.23 & -0.17 & 51.09 & 1.15 & -0.01 & -0.01 & 0.06 \\
\hline Built up areas & 154.45 & 3.28 & 1239.67 & 15.61 & -839.93 & -18.89 & 0.16 & 0.78 & -0.94 \\
\hline Total change & 4702.6 & 100.00 & 7943.42 & 100.00 & 4446.83 & 100.00 & & & \\
\hline
\end{tabular}

Change detection analysis (Table 10) reveals that there was remarkable increase in annual rate of change in the bare soil within Ondo state, the results show that between 2003 to 2008 it was $(-1.52 \%)$, $(-1.00 \%)$ in 2008 to 2013 , and increase (2.44) in 2013 to 2018 . Vegetated soil lost with an annual rate of $-3.31 \%$ (2003-2008) and increase 3.21 (2008-2013), and decreased between with an annual rate of $1.56 \%$ (2013-2018). Water bodies decreased between 2003 to 2013 and increased in 2018. During 2003 to 2008 and 2013 the built-up area increased and decreased by $0.94 \%$.

Figure 16 to Figure 19 shows the various land use by the different classes between 2003 and 2018 . The area of increase and decrease of each class is shown the map.

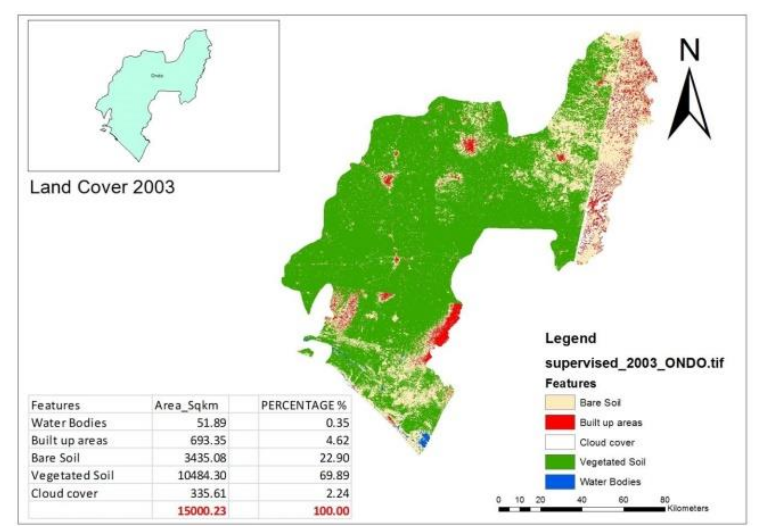

Figure 16: Land cover map - Ondo 2003

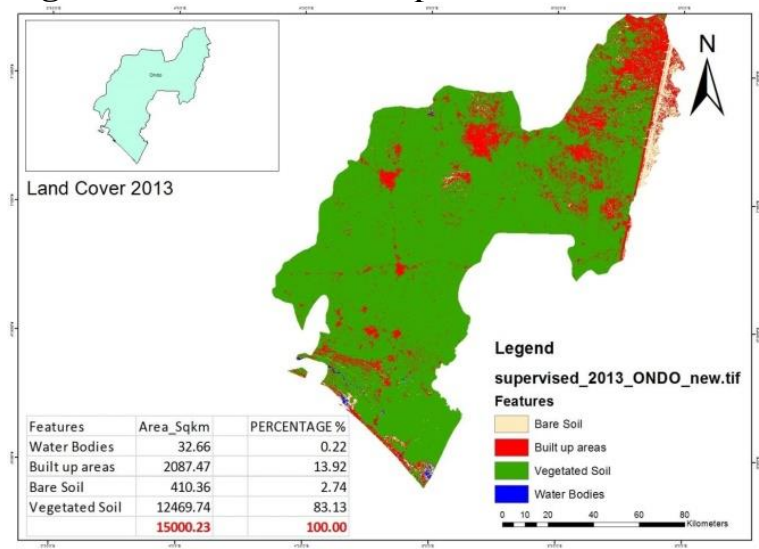

Figure 18: Land cover map - Ondo 2013

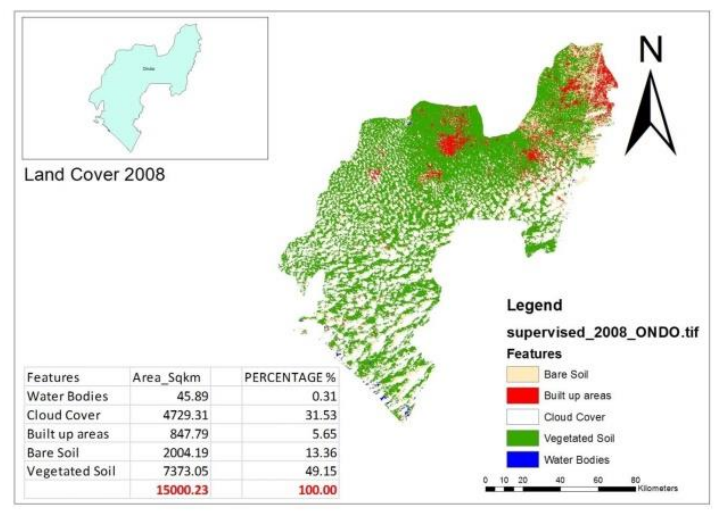

Figure 17: Land cover map - Ondo 2008

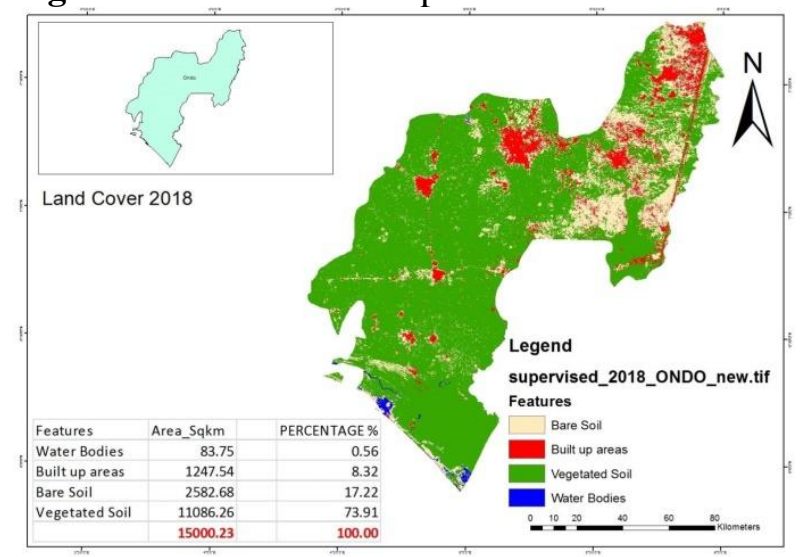

Figure 19: Land cover map - Ondo 2018 


\subsection{Osun State}

The land cover distribution of Osun State for the 4 periods is shown in Table 11. The table reveals that bare soil appreciated within the study period from $0.50 \%$ to $10.66 \%$ and in 2018 to $20.09 \%$. Vegetated soil occupied appreciated by $73.59 \%$ in 2018 . Water bodies also had an increase between 2013 to 2018. There was a decrease in built up area from $14.23 \%$ to $6.12 \%$ between 2013 to 2018 .

Table 11: Land cover distribution of Osun State (2003, 2008, 2013, and 2018)

\begin{tabular}{|l|l|l|l|l|l|l|l|l|}
\hline \multirow{2}{*}{ Feature class } & \multicolumn{2}{|c|}{2003} & \multicolumn{2}{c|}{2008} & \multicolumn{2}{c|}{2013} & \multicolumn{2}{c|}{2018} \\
\cline { 2 - 10 } & Area $\left(\mathrm{km}^{2}\right)$ & Area $(\%)$ & Area $\left(\mathrm{km}^{2}\right)$ & Area $(\%$ & Area $\left(\mathrm{km}^{2}\right)$ & Area $(\%)$ & Area $\left(\mathrm{km}^{2}\right)$ & Area $(\%)$ \\
\hline Bare soil & 43.39 & 0.50 & 915.97 & 10.66 & 102.07 & 1.19 & 1727.08 & 20.09 \\
\hline Vegetated soil & 4507.81 & 52.45 & 6011.55 & 69.94 & 5065.56 & 58.94 & 6325.18 & 73.59 \\
\hline Water bodies & 11.13 & 0.13 & 14.85 & 0.17 & 12.13 & 0.14 & 16.56 & 0.19 \\
\hline Built up areas & 801.23 & 9.32 & 825.41 & 9.60 & 1222.71 & 14.23 & 526.30 & 6.12 \\
\hline Cloud cover & 3231.55 & 37.60 & 827.35 & 9.63 & 2192.64 & 25.51 & - & - \\
\hline Total & 8595.12 & 100.00 & 8595.12 & 100.00 & 8595.12 & 100.00 & 8595.12 & 100.00 \\
\hline
\end{tabular}

Table 12: Trend of land cover changes in Osun State for 2003, 2008, 2013 and 2018

\begin{tabular}{|l|l|l|l|l|l|l|l|l|l|}
\hline \multirow{2}{*}{ Feature class } & \multicolumn{2}{|c|}{$2003-2008$} & \multicolumn{2}{c|}{$2008-2013$} & \multicolumn{2}{c|}{$2013-2018$} & \multicolumn{3}{c|}{ Annual rate of change } \\
\cline { 2 - 11 } & $\begin{array}{l}\text { Area change } \\
\left(\mathrm{km}^{2}\right)\end{array}$ & $\begin{array}{l}\% \text { of } \\
\text { change }\end{array}$ & $\begin{array}{l}\text { Area change } \\
\left(\mathrm{km}^{2}\right)\end{array}$ & $\begin{array}{l}\% \text { of } \\
\text { change }\end{array}$ & $\begin{array}{l}\text { Area change } \\
\left(\mathrm{km}^{2}\right)\end{array}$ & $\begin{array}{l}\% \text { of } \\
\text { change }\end{array}$ & $\begin{array}{l}2003- \\
2008 \\
(\%)\end{array}$ & $\begin{array}{l}2008- \\
2013 \\
(\%)\end{array}$ & $\begin{array}{l}2013- \\
2018 \\
(\%)\end{array}$ \\
\hline Bare soil & 872.58 & 36.29 & -813.89 & -37.68 & 1625.01 & 45.32 & 1.81 & -1.88 & 2.27 \\
\hline Vegetated soil & 1503.74 & 62.55 & -945.98 & -43.80 & 1259.61 & 35.13 & 3.13 & -2.19 & 1.76 \\
\hline Water bodies & 3.72 & 0.15 & -2.72 & -0.13 & 4.44 & 0.12 & 0.01 & -0.01 & 0.01 \\
\hline Built up areas & 24.17 & 1.01 & 397.31 & 18.39 & -696.42 & -19.42 & 0.05 & 0.92 & -0.97 \\
\hline Total change & 2404.21 & 100.00 & 2159.9 & 100.00 & 3585.48 & 100.00 & & & \\
\hline
\end{tabular}

Change detection analysis (Table 12) reveals that there was remarkable decrease in annual rate of change in the bare soil within Osun State, the results show that between 2003 to 2008 it was (-1.81 $\%),(-1.88 \%)$ in 2008 to 2013, and increased by (2.27) in 2013 to 2018. Vegetated soil lost with an annual rate of $3.13 \%$ (2003-2008) and -2.19 (2008-2013), and gained between with an annual rate of $1.76 \%$ (2013-2018). Water bodies represented $2.04 \%$ changes with an annual rate of $0.01 \%$ between 2003 and 2008. From 2008 to 2013, the annual rate of change was $-0.01 \%$ and $0.01 \%$ (2013-2018). During the period of 2003 and 2008, built-up area had an annual rate of $0.05 \%$. From 2008 to 2013, the annual rate of change was $0.92 \%$, and decreased by $-0.97 \%$ between 2013 and 2018 .

Figure 20 to Figure 23 shows the various land use by the different classes between 2003 and 2018 . The area of increase and decrease of each class is shown the map.

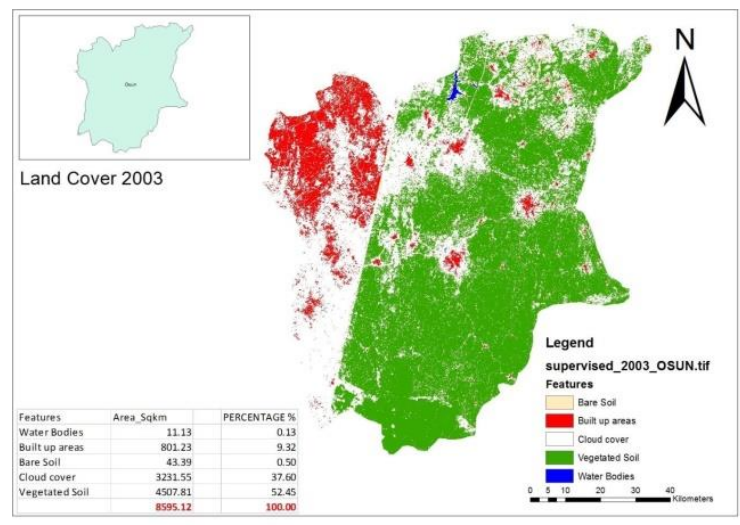

Figure 20: Land cover map - Osun 2003

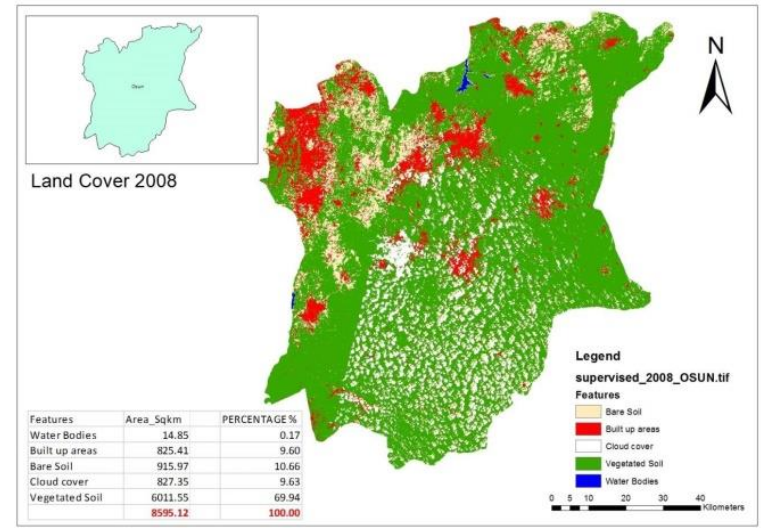

Figure 21: Land cover map - Osun 2008 


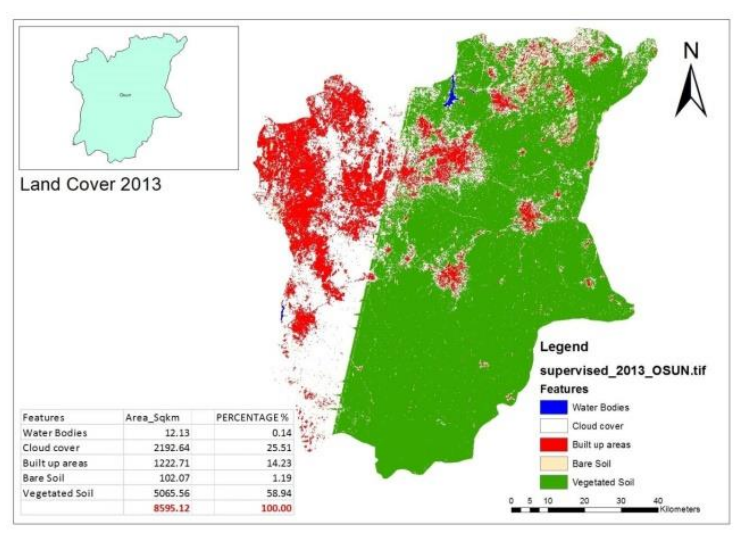

Figure 22: Land cover map - Osun 2013

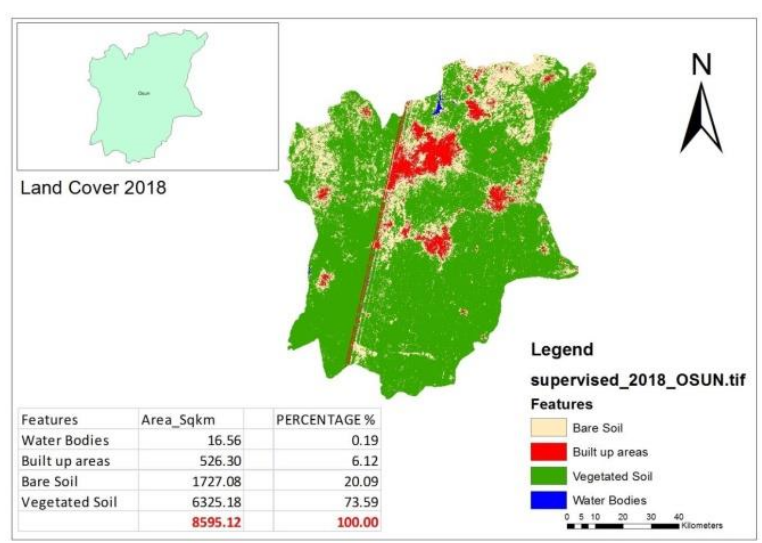

Figure 23: Land cover map - Osun 2018

\subsection{Oyo State}

The land cover distribution of Oyo State for the 4 periods is shown in Table 13. The table reveals that bare soil appreciated from $31.63 \%$ to $86.61 \%$ within the study period. Vegetated soil depreciated from 2003 to 2018. Water bodies also depreciated from 2003 to 2018. There was a general increase in the coverage area of built up areas within the study period 2003 to 2008 and decreased from 2013 to 2018.

Table 13: Land cover distribution of Oyo State (2003, 2008, 2013, and 2018)

\begin{tabular}{|l|l|l|l|l|l|l|l|l|}
\hline \multirow{2}{*}{ Feature class } & \multicolumn{2}{|c|}{2003} & \multicolumn{2}{c|}{2008} & \multicolumn{2}{c|}{2013} & \multicolumn{2}{c|}{2018} \\
\cline { 2 - 10 } & Area $\left(\mathrm{km}^{2}\right)$ & Area $(\%)$ & Area $\left(\mathrm{km}^{2}\right)$ & Area $(\%)$ & Area $\left(\mathrm{km}^{2}\right)$ & Area $(\%)$ & Area $\left(\mathrm{km}^{2}\right)$ & Area $(\%)$ \\
\hline Bare soil & 8797.34 & 31.63 & 4033.90 & 14.48 & 1729.99 & 6.21 & 24151.23 & 86.61 \\
\hline Vegetated soil & 9794.80 & 35.21 & 9053.04 & 32.51 & 6601.23 & 23.70 & 2547.59 & 9.14 \\
\hline Water bodies & 43.67 & 0.16 & 44.73 & 0.16 & 41.82 & 0.15 & 39.92 & 0.14 \\
\hline Built up areas & 8953.65 & 32.19 & 14717.15 & 52.85 & 3963.06 & 14.23 & 1146.28 & 4.11 \\
\hline Cloud cover & 225.58 & 0.81 & 0.00 & 0.00 & 15511.71 & 55.70 & 0.00 & 0.00 \\
\hline Total & 27815.03 & 100.00 & 27848.82 & 100.00 & 27847.82 & 100.00 & 27885.02 & 100.00 \\
\hline
\end{tabular}

Table 14: Trend of Land cover changes in Oyo State for 2003, 2008, 2013 and 2018

\begin{tabular}{|c|c|c|c|c|c|c|c|c|c|}
\hline \multirow[b]{2}{*}{ Feature class } & \multicolumn{2}{|c|}{$2003-2008$} & \multicolumn{2}{|c|}{$2008-2013$} & \multicolumn{2}{|c|}{$2013-2018$} & \multicolumn{3}{|c|}{ Annual rate of change } \\
\hline & $\begin{array}{l}\text { Area change } \\
\left(\mathrm{km}^{2}\right)\end{array}$ & $\begin{array}{l}\% \text { of } \\
\text { change }\end{array}$ & $\begin{array}{l}\text { Area change } \\
\left(\mathrm{km}^{2}\right)\end{array}$ & $\begin{array}{l}\% \text { of } \\
\text { change }\end{array}$ & $\begin{array}{l}\text { Area change } \\
\left(\mathrm{km}^{2}\right)\end{array}$ & $\begin{array}{l}\% \text { of } \\
\text { change }\end{array}$ & $\begin{array}{l}2003- \\
2008 \\
(\%)\end{array}$ & $\begin{array}{l}2008- \\
2013 \\
(\%)\end{array}$ & $\begin{array}{l}2013- \\
2018 \\
(\%)\end{array}$ \\
\hline Bare soil & -4763.44 & -42.27 & -2303.91 & -14.85 & 22421.24 & 76.54 & -2.11 & -0.74 & 3.83 \\
\hline Vegetated soil & -741.76 & -6.58 & -2451.81 & -15.81 & -4053.64 & -13.84 & -0.33 & -0.79 & -0.69 \\
\hline Water bodies & 1.06 & 0.01 & -2.91 & -0.02 & -1.90 & -0.01 & 0.00 & 0.00 & 0.00 \\
\hline Built up areas & 5763.50 & 51.14 & -10754.09 & -69.32 & -2816.78 & -9.62 & 2.56 & -3.47 & -0.48 \\
\hline Total change & $11,269.76$ & 100.00 & 15512.72 & 100.00 & 29293.56 & 100.00 & & & \\
\hline
\end{tabular}

Change detection analysis (Table 14) reveals that there was remarkable decrease in annual rate of change in the bare soil within Oyo State, the results show that between 2003 to 2008 it was $(-2.11 \%)$, $(-0.74 \%)$ in 2008 to 2013, and increased (3.83) in 2013 to 2018. Vegetated soil lost occurred between (2003-2008), (2008-2013) and (2013-2018). Water bodies didn't change, during the period of 2003 and 2008, built-up area was representing had an annual rate of 2.56\%. From 2008 to 2013, the annual rate of change was $-3.47 \%$, and $-0.48 \%$ between 2013 and 2018 .

Figure 24 to Figure 27 shows the various land use by the different classes between 2003 and 2018 . The area of increase and decrease of each class is shown the map. 


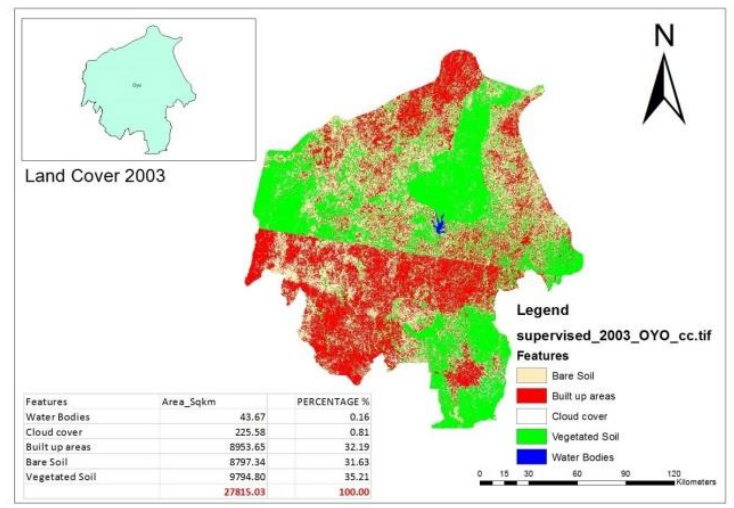

Figure 24: Land cover map - Oyo 2003

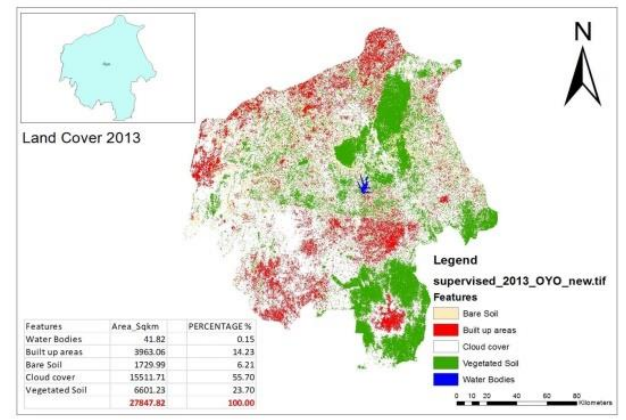

Figure 26: Land cover map - Oyo 2013

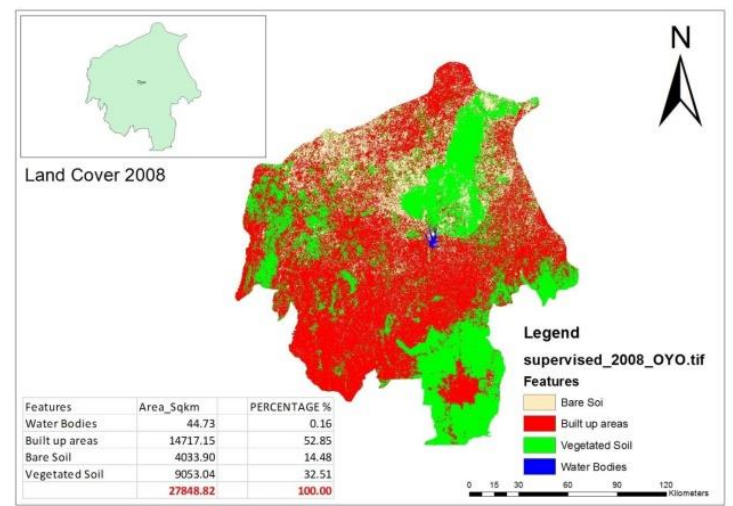

Figure 25: Land cover map - Oyo 2008

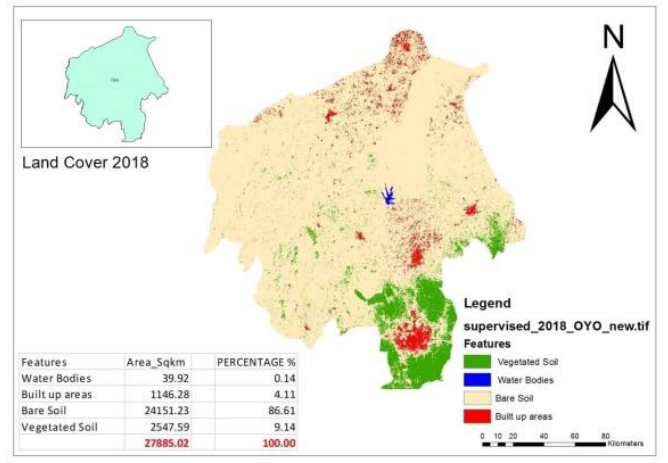

Figure 27: Land cover map - Oyo 2018

\subsection{South-West Geopolitical Zone}

The land cover distribution of South West zone for the 4 epochs is shown in Table 15. The table reveals that bare soil lost to other land cover classes from $20.34 \%$ to $3.47 \%$ within the period of 20032013 and increased greatly from $3.47 \%$ to $38.28 \%$ between the period of 2013 to 2018 . Vegetated soil remains relatively steady with an average of $50.37 \%$ of area coverage within the study period. Water bodies occupied an average of $1.12 \%$ of the area within the 4 epochs. Built up areas remain steady at an average of $21.2 \%$.

Table 15: Land cover distribution of South West zone (2003, 2008, 2013, and 2018)

\begin{tabular}{|l|l|l|l|l|l|l|l|l|}
\hline \multirow{2}{*}{ Feature class } & \multicolumn{2}{|c|}{2003} & \multicolumn{2}{c|}{2008} & \multicolumn{2}{c|}{2013} & \multicolumn{2}{c|}{2018} \\
\cline { 2 - 9 } & Area $\left(\mathrm{km}^{2}\right)$ & Area $(\%)$ & Area $\left(\mathrm{km}^{2}\right)$ & Area $(\%)$ & Area $\left(\mathrm{km}^{2}\right)$ & Area $(\%)$ & Area $\left(\mathrm{km}^{2}\right)$ & Area $(\%)$ \\
\hline Bare soil & 15803.56 & 20.34 & 7884.62 & 10.14 & 2694.38 & 3.47 & 29772.18 & 38.28 \\
\hline Vegetated soil & 41226.24 & 53.05 & 41628.51 & 53.54 & 38104.05 & 49.01 & 35683.94 & 45.88 \\
\hline Water bodies & 829.58 & 1.07 & 981.79 & 1.26 & 845.83 & 1.09 & 835.51 & 1.07 \\
\hline Built up areas & 15965.64 & 20.54 & 21239.76 & 27.32 & 17225.49 & 22.16 & 11492.72 & 14.78 \\
\hline Cloud cover & 3889.36 & 5.00 & 6013.48 & 7.73 & 18877.41 & 24.28 & 0.00 & 0.00 \\
\hline Total & 77714.37 & 100.00 & 77748.16 & 100.00 & 77747.16 & 100.00 & 77784.36 & 100.00 \\
\hline
\end{tabular}

Table 16: Trend of land cover changes in South West Zone for 2003, 2008, 2013 and 2018

\begin{tabular}{|c|c|c|c|c|c|c|c|c|c|}
\hline \multirow[b]{2}{*}{ Feature class } & \multicolumn{2}{|c|}{$2003-2008$} & \multicolumn{2}{|c|}{$2008-2013$} & \multicolumn{2}{|c|}{$2013-2018$} & \multicolumn{3}{|c|}{ Annual rate of change } \\
\hline & $\begin{array}{l}\text { Area change } \\
\left(\mathrm{km}^{2}\right)\end{array}$ & $\begin{array}{l}\% \text { of } \\
\text { change }\end{array}$ & $\begin{array}{l}\text { Area change } \\
\left(\mathrm{km}^{2}\right)\end{array}$ & $\begin{array}{l}\% \text { of } \\
\text { change }\end{array}$ & $\begin{array}{l}\text { Area change } \\
\left(\mathrm{km}^{2}\right)\end{array}$ & $\begin{array}{l}\% \text { of } \\
\text { change }\end{array}$ & $\begin{array}{l}2003- \\
2008 \\
(\%)\end{array}$ & $\begin{array}{l}2008- \\
2013 \\
(\%)\end{array}$ & $\begin{array}{l}2013- \\
2018 \\
(\%)\end{array}$ \\
\hline Bare soil & -7918.95 & -57.60 & -5190.24 & -40.34 & 27077.80 & 76.84 & -2.88 & -2.02 & 3.84 \\
\hline Vegetated soil & 402.28 & 2.93 & -3524.46 & -27.40 & -2420.11 & -6.87 & 0.15 & -1.37 & -0.34 \\
\hline Water bodies & 152.21 & 1.11 & -135.96 & -1.06 & -10.31 & -0.03 & 0.06 & -0.05 & 0.00 \\
\hline Built up areas & 5274.13 & 38.36 & -4014.28 & -31.20 & -5732.76 & -16.27 & 1.92 & -1.56 & -0.81 \\
\hline Total & 13747.57 & 100.00 & 12864.94 & 100.00 & 35240.98 & 100.00 & & & \\
\hline
\end{tabular}

Change detection analysis (Table 16) reveals that bare soil had an annual rate of -2.88\% (2003-2008), $-2.02 \%$ (2008-2013) and 3.84\% (2013-2018). Vegetated soil has an annual rate of $0.15 \%$ (20032008), $-1.37 \%$ (2008-2013) and $-0.34 \%$ (2013-2018). Built up areas was represented with $38.36 \%$ changes with an annual rate of $1.92 \%$ from 2003 to 2008. From 2008-2013, it lost with an annual rate of $-1.56 \%$, and $-0.81 \%$ (2013-2018). 


\subsection{Conclusions}

Land use and land cover data are important for an understanding of how environmental systems function, and their assessment over time provides a means for assessing the impact that any changes in land use may have on biodiversity and ecosystems. The ability to detect land cover changes over time with remote sensing offers the possibility of more frequent monitoring. The results of this research show that Landsat data are very useful in monitoring land-cover types at a broad level of classification such as bare soil, vegetated soil, water bodies etc. for a regional area or state over a period a time. The research focused on the spatio-temporal changes that have taken place in the south western states of Nigeria and it was observed that, bare soil lost its land cover to other land cover classes from $20.34 \%$ to $3.47 \%$ within the period of $2003-2013$ and increased greatly from $3.47 \%$ to $38.28 \%$ between the period of 2013 to 2018 . Vegetated soil remains relatively steady with an average of $50.37 \%$ of area coverage within the study period. Water bodies occupied an average of $1.12 \%$ of the area within the 4 epochs. Built up areas remain steady at an average of $21.2 \%$. Bare soil had an annual reduction rate of $-2.88 \%$ (2003-2008), $-2.02 \%(2008-2013)$ and increased in $3.84 \%$ (20132018). Vegetated soil has an annual rate of $0.15 \%$ (2003-2008), $-1.37 \%(2008-2013)$ and $-0.34 \%$ (2013-2018). Built up areas was represented with $38.36 \%$ changes with an annual rate of $1.92 \%$ from 2003 to 2008. From 2008-2013, it lost with an annual rate of $-1.56 \%$, and $-0.81 \%$ (2013-2018).

It is recommended from the results obtained from the analysis that government should reserve the land classes that are reducing in area which are bare soil and vegetation for future economic use because these land classes are being taken over by built up area in each state of the south western region of Nigeria. The vegetation and bare soil can serve as animal abode, tourism, preservation of the ecosystem. Depletion in vegetation poised a great danger that could cause greenhouse effect on the environment. Each state should adopt policies that can checkmate the effect of reduction in vegetation to urbanization and postulate environmental education protection and conservation forest, Local, state and Federal Government to maintained and save our ecological biodiversity.

\section{References}

Agene J.I. and Haruna A. I (2017). Study of Land Cover Change Analysis around Obajana, Kogi State, Nigeria: A Geoinformatics Approach. International Journal of Scientific \& Engineering Research Volume 8, Issue 6, June-2017 979 ISSN 2229-5518

Baulies. X, Szejwach. G (1998). LUCC Data Requirements Workshop Survey of Needs, Gaps and Priorities on Data for Land-Use/Land-Cover Change Research Organized by IGBP/IHDP-LUCC and IGBP-DIS

EEA (2018). Copernicus Land Monitoring Service - High Resolution Layers - Imperviousness. Published 15 May 2018. https://www.eea.europa.eu/data-and-maps/data/copernicus-land-monitoringservice-imperviousness-2

Ekong P.S, Ducheyne E, Carpenter T.E, Owolodun O.A, Oladokun A.T, Lombin L.H, Berkvens D.(2012). Spatio-temporal epidemiology of highly pathogenic avian influenza (H5N1) outbreaks in Nigeria, 2006-2008.Preventive Veterinary Medicine. Preventive Veterinary Medicine 103 (2012) $170-177$

Jande et al., (2019). Assessment of land use and land cover changes and urban expansion using Remote sensing and GIS in gboko, Benue state, Nigeria. Journal of research in forestry, wildlife \& environment vol. 11(3) September, 2019. http://www.ajol.info/index.php/jrfwe jfewr @2019 - jfewr publications ISBN: $2141-1778$

Liang.S, Fang.H, Morisette, J.T, Chen.M. Shuey C.J., Walthall C.L and Daughtry, C.S (2002).Atmospheric Correction of Landsat ETM+ Land Surface Imagery: II. Validation an application. IEEE Transactions on Geoscience and Remote Sensing.

Ndukwe N.K (1997): Principles of Environmental Remote Sensing and Photo Interpretation New Concept Publishers Enugu. 
Owoeye .J and Akinluyi F (2018). Geospatial Analysis of Land Cover Change and Urban Sprawl Trend in Akure Region, Nigeria. MOJ Eco Environ Sci 3(1): 00062. DOI: 10.15406/mojes.2018.03.00062

Perrings C.S, Naeem F.S, Ahrestani D.E, Bunker P, Burkill G, Canziani T, Elmqvist J.A. Fuhrman F.M, Jaksic Z, Kawabata A, Kinzig G.M, Mace, H, Mooney A.H, Prieur-Richard, J. T and Weisser W. (2011). Ecosystem services, targets, and indicators for the conservation and sustainable use of biodiversity. Frontiers in Ecology and the Environment 9: 512-520.

Richards, J.A., (1999). Remote Sensing Digital Image Analysis, Springer-Verlag, Berlin, p. 240 Wilkie, D.S., and Finn, J.T. (1996). Remote Sensing Imagery for Natural Resources Monitoring. Columbia University Press, New York. p. 295.

Cite this article as:

Oseni A. E. and Ode G. O., 2020. Spatio-temporal Analysis of South Western States of Nigeria using Remote Sensing Techniques. Nigerian Journal of Environmental Sciences and Technology, 4(2), pp. 298313. https://doi.org/10.36263/nijest.2020.02.0196 